\title{
Consensus on the competencies required for public health nutrition workforce development in Europe - the JobNut project
}

\author{
Svandis Jonsdottir ${ }^{1}$, Roger Hughes ${ }^{2, *}$, Inga Thorsdottir ${ }^{1}$ and Agneta Yngve 3,4 \\ 'Unit for Nutrition Research, Faculty of Food Science and Nutrition, School of Health Sciences, University of \\ Iceland and Landspitali-University Hospital, Reykjavik, Iceland: ${ }^{2}$ School of Health and Sports Sciences, \\ University of the Sunshine Coast, Maroochydore, QLD 4558, Australia: ${ }^{3}$ Akershus University College, Lillestrom, \\ Norway: ${ }^{4}$ Department of Biosciences and Nutrition, Karolinska Institutet, Huddinge, Sweden
}

Submitted 15 September 2009: Accepted 17 February 2010: First published online 31 March 2010

\begin{abstract}
Objective: To assess and develop consensus among a European panel of public health nutrition stakeholders regarding the competencies required for effective public health nutrition practice and the level of proficiency required in different practice contexts.

Design: A modified Delphi study involving three rounds of questionnaires.

Setting: European Union.

Subjects: Public health nutrition workforce development stakeholders, including academics, practitioners and employers, from twenty European countries.

Results: A total of fifty-two expert panellists (84\% of an initial panel of sixty-two Delphi participants) completed all three rounds of the Delphi study. The panellists rated the importance of fifty-seven competency units possibly required of a public health nutritionist to effectively practice (Essential competencies). Twentynine of the fifty-seven competency units (51\%) met the consensus criteria ( $\geq 66.7 \%$ agreement) at the second round of the Delphi survey, with the highest agreement for competencies clustered within the Nutrition science, Professional, Analytical and Public bealth services competency domains. Ratings of the level of competencies required for different levels in the workforce indicated that for a public health nutrition specialist, advanced-level competency was required across almost all the twenty-nine competencies rated as essential. There were limited differences in rating responses between academics and employer panellists throughout the Delphi study.

Conclusions: Competencies identified as essential can be used to review current public health nutrition practices and provide the basis for curriculum design and re-development, continuing education and workforce quality assurance systems in Europe. These are all important tools for systematic and strategic workforce development.
\end{abstract}

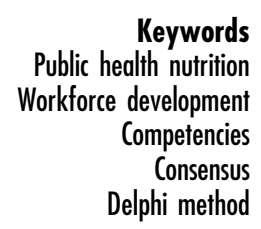

The capacity of the public health workforce is a key contributor to the ability of communities to address public health nutrition issues ${ }^{(1)}$. Workforce capacity is influenced by a range of determinants including the quality of workforce preparation and continuing professional development, workforce size, organisation and support ${ }^{(2)}$. With respect to workforce preparation and continuing professional development, competency-based approaches have been widely embraced recently as a process central to the professionalisation of public health and its related disciplinary groups ${ }^{(3-7)}$, including public health nutrition ${ }^{(7)}$.

In the European context, workforce development that encourages optimal workforce mobility and collaboration in research and practice requires the development of comparably competent practitioners who are capable of developing and undertaking effective population-based strategies to meet nutrition and public health objectives. This has been the position of workforce development scholars for at least the last decade ${ }^{(8,9)}$. Competency standards provide the architecture for workforce development by codifying the knowledge, skills and attitudes necessary to effectively practise public health nutrition $^{(10)}$. They have a deliberate focus on effective performance in the workplace, ensuring that workforce preparation and continuing professional development not only enhance what practitioners 'know', but also that they 'know how', can 'show how' and 'do',(11).

Competency standards serve a number of workforce development functions, including providing a structure for the design and evaluation of curricula that promote 
minimum standards, assessing individuals in terms of fitness to practice, directing continuing professional development and assisting job evaluation and design. The utility of competency standards as a tool for workforce development is increasingly being recognised worldwide. Competencies specific to public health nutrition have been of interest to workforce developers in the USA for at least three decades ${ }^{(8,12,13)}$. In Australia, advanced-level competencies have been proposed to help delineate the roles and workforce development needs required for this developing workforce $^{(7)}$ and competencies have been codified as a basis for public health nutritionist registration ${ }^{(14)}$. In Europe, the Nutrition Society in the UK has developed a system for registration of public health nutrition practitioners as a public protection and quality assurance measure ${ }^{(15,16)}$ and this has included consideration of competency issues ${ }^{(16)}$.

Attempts to assess consensus on the competency needs of public health nutritionists in the early 2000s demonstrated a high level of agreement on essential public health nutrition competencies identified by an international panel of public health nutrition experts from the USA, Europe and Australia $^{(17)}$. Although panellists were recruited from a limited range of cultural and health system contexts, this finding supported the suggestion that competencies required for effective public health nutrition practice are largely consistent across countries and settings (at least among developed countries) and that workforce development for public health nutrition can be based on a consensus set of competencies that are transferable across jurisdictions and in different contexts ${ }^{(10,18)}$. Many of these competencies identified were similar to those of general public health practice ${ }^{(3,5-7)}$, but with a consistent provision that the public health nutrition workforce requires additional competency units in nutritional sciences ${ }^{(18)}$. This earlier scholarship focusing on public health nutrition competencies has promoted a premise that the mix and level of competency required by an individual practitioner will vary in different practice contexts, but that there is a core set of essential competencies required for a practitioner to be assessed as competent ${ }^{(19)}$.

Given this potential utility of competency standards for workforce development efforts with currency in different national contexts, the development of consensus on competency standards in the pan-European context is important. The aim of the present study was to assess and develop consensus among public health nutrition workforce development stakeholders in Europe on essential competencies for the effective practice of public health nutrition, and the level of proficiency required at different levels of practice.

\section{Methods}

A modified Delphi study, based on an earlier consensus development study focusing on public health nutrition competencies $^{(10)}$, was implemented among workforce development stakeholders from across Europe. It included, as shown in Fig. 1, a definition of the problem through gathering of current intelligence, identification and recruitment of panellists, followed by a three-step process for identifying consensus in the panel. The Delphi study's primary advantages in this context are cost-effectiveness and the ability to harness the anonymous ideas and opinions of a range of experts/stakeholders in different geographic locations. The Delphi method is a frequently used technique to measure and aid forecasting and decision making in a variety of disciplines ${ }^{(20,21)}$, including competency requirements in health-care settings ${ }^{(20)}$. Four key features define the Delphi method: anonymity, iteration, controlled feedback and the statistical aggregation of group response ${ }^{(21)}$.

\section{Expert panel recruitment}

The Delphi method does not call for expert panels to be representative samples for statistical purposes. Representativeness is assessed on the qualities of the expert panel rather than its numbers ${ }^{(22)}$. There seems to be very little actual empirical evidence on the effect of the number of participants on the reliability or validity of consensus processes $^{(20)}$. Limited guidance therefore exists on the minimum or maximum number of experts on a Delphi panel. It appears to be related to common sense and practical logistics $^{(23)}$.

An email contact list for European public health nutrition workforce development stakeholders was developed, primarily through snowball sampling from existing professional networks and a list of contacts developed by internet search of websites of European universities, official websites of public health nutrition-related research projects, conferences and workshops, and through the Nutrition Society website.

The inclusion criterion for individuals invited to become panellists was that they were required to be in positions relevant to influencing and practising workforce development (e.g. employers in public health agencies, academics and senior practitioners). The assumption used when identifying panellists this way was that individuals employed or practising in senior-level positions within health and academic institutions had the necessary experience and insight to be considered experts in this context.

The final contact list comprised 159 identified experts across Europe, who were formally invited via email to join the pan-European expert panel and participate in the Delphi process with an explicit request to either selfnominate or forward invitations to known experts. Panellists who accepted the invitation (i.e. expert selfselection) were forwarded the first Delphi questionnaire as an email attachment for completion and email return. Figure 1 illustrates the process used in this study. 


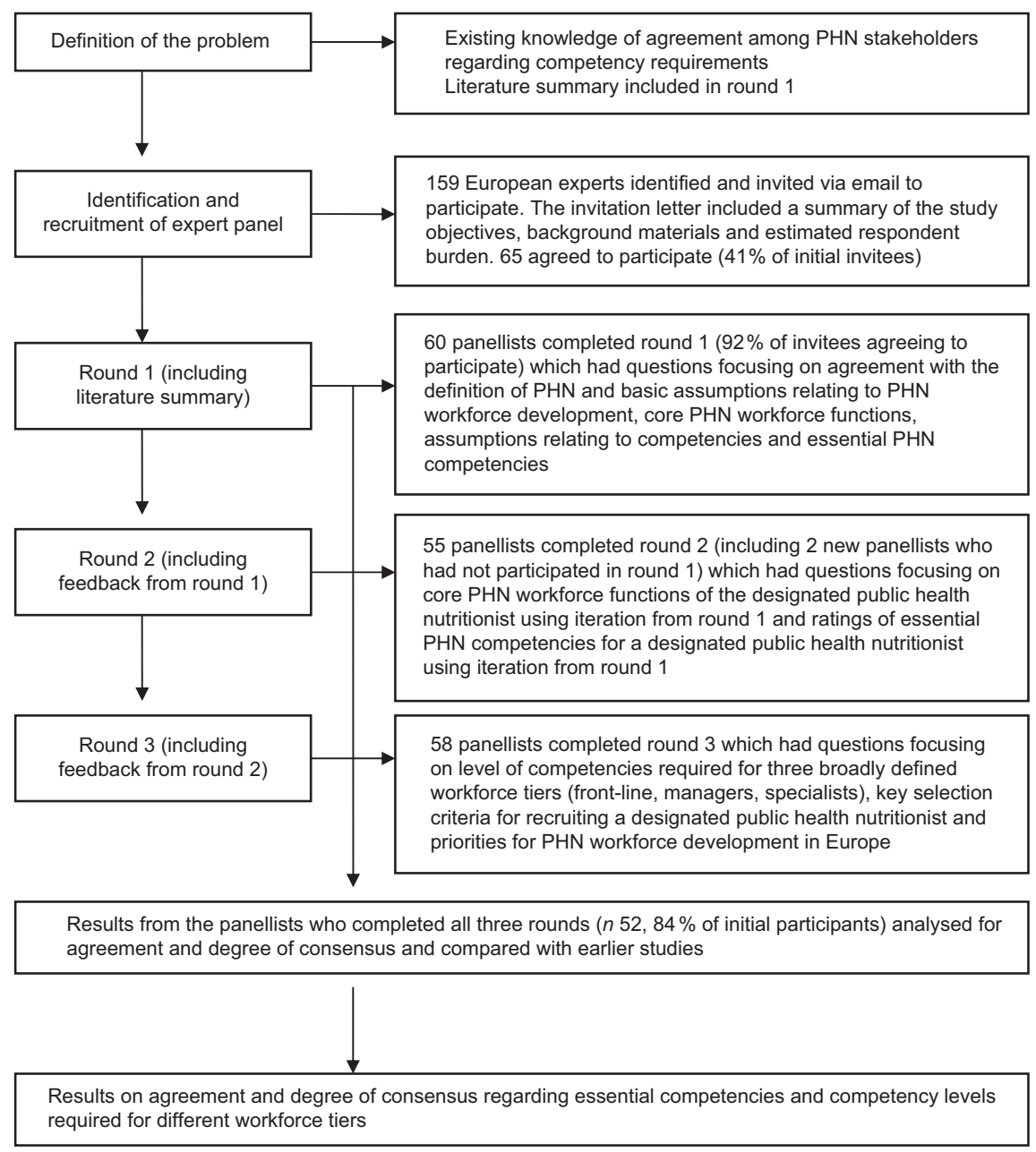

Fig. 1 Schematic overview of the Delphi process (adapted from reference (10); PHN, public health nutrition)

\section{Survey instruments}

Each survey round of the Delphi process used survey instruments based on an earlier study that assessed consensus among an international panel regarding the essential competencies required for effective public health nutrition practice. The competency units tested in these survey rounds were originally constructed from competency standards in the public health, health promotion and dietetics fields of practice ${ }^{(10)}$. The present study varied from the traditional Delphi method in that structured questions informed by this earlier study were used rather than open-ended questions.

Table 1 summarises the focus of inquiry in each survey round.

\section{Ratings of levels of competency required by different workers (round 3)}

The fifty-seven public health nutrition competency units tested in Delphi survey rounds 1 and 2 were tested for the level of competency required by three broadly defined workforce groups using the definitions in Table 2 .
Table 1 Focus of the Delphi survey round questions used in Rounds 1 to 3

\begin{tabular}{ll}
\hline Round & \multicolumn{1}{c}{ Focus on assessing consensus on } \\
\hline 1 & Definition of public health nutrition \\
& Basic assumptions relating to public health nutrition \\
workforce development \\
Basic assumptions relating to public health nutrition \\
competencies \\
Rating of fifty-seven competency units required by an \\
individual public health nutrition practitioner \\
(Essential, Useful or Irrelevant)
\end{tabular}

*Essential competencies defined as competencies without which public health nutrition practice effectiveness is limited ${ }^{(10,19)}$. Useful competencies defined as competencies that are required occasionally or in specific contexts only.

\section{Data analysis}

Responses to each round of Delphi surveys were entered into Microsoft ${ }^{\circledR}$ Office Excel 2003 (Microsoft Corporation, 
Table 2 Definitions of worker category and level of competency used in rating competencies in round 3

\begin{tabular}{ll}
\hline $\begin{array}{l}\text { Worker category } \\
\text { Front-line staff }\end{array}$ & Definition \\
Managers/supervisors & $\begin{array}{c}\text { Individuals who implement the bulk of day-to-day public health nutrition tasks and services, often as part } \\
\text { of wider generalist health roles. May have responsibilities other than nutrition (e.g. individual care } \\
\text { dietitians, community-based nurses, general medical practitioners, health educators, health promoters) } \\
\text { Individuals responsible for major programmes or health service functions, usually with managerial } \\
\text { responsibility for specialist and generalist health worker teams, and involved in resource management } \\
\text { and policy processes (e.g. Directors of Public Health or Community Health Services) } \\
\text { Individuals with designated functions reflecting specialisation in the practice of public health nutrition, } \\
\text { often with a title reflecting that role. May include practitioners or academics actively engaged in public } \\
\text { health nutrition efforts/services (e.g. public health nutritionist, community nutritionist, academic public } \\
\text { health nutritionist) } \\
\text { Practitioner aware of issues or skills but has limited ability to apply competencies independent of support } \\
\text { and supervision from someone more competent. KNOWS: has knowledge of topic, issues } \\
\text { Somewhere between basic and advanced knowledge and skill in applications of the competency unit, but } \\
\text { may still require occasional supervision or support from advanced competency practitioners to be } \\
\text { Intermediate level } \\
\text { effective. KNOWS HOW: has knowledge of processes and approaches relevant to practice } \\
\text { Practitioner proficient in the application of the competency as part of effective practice, not requiring } \\
\text { supervision or support. Often providing leadership in competency application. SHOWS HOW AND } \\
\text { DOES: can apply knowledge and skills to perform functions and tasks }\end{array}$ \\
Advanced level &
\end{tabular}

Redmond, WA, USA) for storage. The data were imported to the SPSS for Windows statistical software package version $11 \cdot 0$ (SPSS Inc., Chicago, IL, USA) for determination of frequency of response distributions and $\chi^{2}$ analysis for differences in distribution between academic $v$. employer panellists. The level of significance was taken as $P<0 \cdot 05$.

\section{Definition and stability of the consensus}

The literature does not provide any agreed standard on how to measure consensus ${ }^{(21)}$. Arbitrary and predefined consensus rules were used to judge agreement among the panellists and define when consensus had been developed. The consensus standard was arbitrarily set at $\geq 66.7 \%$ agreement (i.e. two out of three panellists agreeing) in all three Delphi rounds. The consensus was considered to have reached stability if group ratings on suggested competencies varied $\leq 10 \%$ between rounds. This approach to define stability of the consensus has been used in previous studies ${ }^{(10,24)}$.

\section{Results}

\section{Characteristics of the Delphi panel}

A total of sixty-two panellists participated in the Delphi study, with fifty-two (84\%) completing all three surveys. Figure 1 provides data on the number of panellists responding in each round. Participating panel members were from twenty countries, seventeen EU countries and three countries which are not EU member states (refer to Acknowledgements: panellists and country for details). Delphi respondents were categorised into two subgroups (employers $v$. academics) based on their current position. About one-third were categorised as employers (e.g. working in public health institutes, ministries, private companies, etc.) and the rest as academics (e.g. university personnel, employees at research institutes, etc.).

\section{Agreement with basic propositions relating to public bealth nutrition workforce development} Table 3 presents levels of agreement on a 5-point Likert scale $(1=$ strong disagreement, $5=$ strong agreement $)$ with a range of propositions relating to public health nutrition workforce development and competencies. These results indicate a high degree of panellist homogeneity in terms of agreement with the definition of public health nutrition and propositions relating to public health nutrition workforce development. There was limited difference in response distributions between panellists categorised as academics $v$. employers, with more academics agreeing with proposition 5 (Table 3 ).

\section{Essential (core) public bealth nutrition competencies}

Table 4 presents data on the proportion of panellists rating competency items considered as essential for a public health nutrition practitioner (from Delphi survey rounds 1 and 2) and the most common response (modal response) for predefined levels of competency required for three different workforce tiers (rounds 2 and 3).

Nineteen of the fifty-seven suggested competency units $(33 \cdot 3 \%)$ were rated as essential by more than the consensus standard of $\geq 66.7 \%$ agreement at the first round. At the second round, twenty-nine competency units or 50.9\% reached the consensus standard and were defined as essential public health nutrition competencies (see Table 4).

Differences in ratings between the two panellist categories (academics $v$. employers) were limited to only two of the competencies defined as essential. Academics rated two specific suggested public health nutrition competencies as essential more often than employers did. These 
Table 3 Response distributions for agreement to propositions relating to public health nutrition workforce development and competencies (Delphi round 1, $n 60$ ), descending order by percentage of agreement or strong agreement

\begin{tabular}{|c|c|}
\hline Proposition & $\begin{array}{l}\text { Strongly agree or } \\
\text { agree* }(\%)\end{array}$ \\
\hline Workforce development for public health nutrition should be multidisciplinary in its focus & 98 \\
\hline $\begin{array}{l}\text { There are many common or cross-cutting competencies between public health and public health nutrition, but the } \\
\text { difference is that public health nutrition requires a competency mix specific to nutrition and an understanding of } \\
\text { nutrition issues }\end{array}$ & 97 \\
\hline $\begin{array}{l}\text { Public health nutrition is the promotion and maintenance of nutrition-related health and well-being of populations } \\
\text { through the organised efforts and informed choices of society }\end{array}$ & 95 \\
\hline The public health nutrition workforce needs a specialist workforce tier to lead and facilitate coordinated action & 95 \\
\hline $\begin{array}{l}\text { Internationally recognised professional standards (e.g. competencies) for a public health nutrition specialist would } \\
\text { be a useful tool for workforce developmentt }\end{array}$ & 88 \\
\hline $\begin{array}{l}\text { Competencies need to reflect the mix of skills, knowledge and attributes of the workforce or work group rather } \\
\text { than just focus on an individual professional group }\end{array}$ & 88 \\
\hline $\begin{array}{l}\text { Competencies for a specialist workforce tier (i.e. public health nutritionists) are needed as a priority because this is } \\
\text { the workforce tier that is needed to facilitate and lead public health nutrition action }\end{array}$ & 83 \\
\hline Public health nutrition competencies can be developed via numerous academic and experience pathways & 79 \\
\hline
\end{tabular}

were Nutrition monitoring and surveillance $\left(\chi^{2}=4 \cdot 7\right.$, $P=0 \cdot 03,97 \cdot 1 \%$ of academics $v .78 \cdot 9 \%$ of employers) and Knowledge of the roles and cultures of other bealth professions in public bealth $\left(\chi^{2}=4 \cdot 7, P=0 \cdot 03,88 \cdot 2 \%\right.$ of academics $v \cdot 63 \cdot 2 \%$ of employers).

The highest agreement among panel members was on competencies clustered within the Analytical, Public bealth services, Nutrition science and Professional headings. Only one suggested competency unit, Values and participates in peer review under the Professional heading, did not reach the consensus limit.

\section{Response stability between rounds}

Only three of the twenty-nine competency units rated as essential at consensus level $(\geq 66 \cdot 7 \%)$ were response stable after two rounds (i.e. changing $\leq 10 \%$ between rounds 1 and 2). In all twenty-nine competency units rated essential at the consensus level, this change between rounds was upwards (increasing between rounds 1 and 2), indicating a strengthening of agreement. For all competency units tested, response stability was reached on twenty-one of the total of fifty-seven suggested competency units $(36 \cdot 8 \%)$.

\section{Level of competency required by workforce level}

For the specialist work category, all but one of the twenty-nine competency units rated as essential to consensus level were also rated as requiring advanced-level competency. The manager level worker category tended to have a mix of advanced- and intermediate-level competency requirements across competency elements, with a definite clustering of advanced-level requirements in the Communication and Management and leadership competency domains. Front-line workers were rated to need basic competency levels across most competency units tested, with higher-level competencies required in competency units reflecting Professional and Nutrition science competency domains. Ratings of competency level required for different workforce levels showed minor variation between academic and employer category panellists, with only four of fifty-seven units being significantly different in response distribution $\left(\chi^{2}\right.$, all $P<0 \cdot 05$, with academics more likely to rate more often than employers).

\section{Discussion}

A basic and logical assumption of the sampling method used to develop the Delphi panel was that individuals occupying academic or senior-level professional roles relevant to public health nutrition were 'experts' in the context of public health nutrition workforce development. Panellist self-selection after invitation is also likely to engage individuals who consider themselves to be experienced and knowledgeable in this field. The sampling method used in the current study achieved higher initial participation and panellist retention across the three survey rounds than the earlier study by Hughes ${ }^{(10)}$, on which the current study was based. The good panellist retention across the three survey rounds ( $n$ 52, 84\% of panellists) indicates their high degree of interest in the topic. The high degree of agreement among panellists with the definition of public health nutrition and a range of workforce development propositions relevant to public health nutrition competencies suggests that this panel was homogeneous in terms of their vision of public health nutrition and opinions regarding the relevance and importance of competencies as a workforce development issue.

Consulting employers about their competency expectations for public health nutritionists has been proposed as an important part of the intelligence gathering required to inform workforce development ${ }^{(25,26)}$. The assumption 
Table 4 Consensus on public health nutrition competency units rated as essential (core) and proportion of ratings for level of competency by workforce level ( $n 52$ panellists completing three rounds)

\begin{tabular}{|c|c|c|c|c|c|}
\hline \multirow[b]{2}{*}{ Competency units } & \multirow{2}{*}{$\begin{array}{l}\% \text { rated as essential } \\
\text { (core) after two rounds }\end{array}$} & \multirow{2}{*}{$\begin{array}{l}\text { Stability: \% change } \\
\text { between rounds } 1 \text { and } 2\end{array}$} & \multicolumn{3}{|c|}{ Workforce category } \\
\hline & & & Specialist & Manager & Front-line \\
\hline ANALYTICAL & & & \multicolumn{3}{|c|}{ Modal response (most common) for each tier (round 3) (\%) } \\
\hline Nutrition monitoring and surveillance ${ }^{*}$ & 91 & $+30 \cdot 3$ & $\begin{array}{l}\text { Advanced } \\
76 \cdot 8\end{array}$ & $\begin{array}{l}\text { Intermediate } \\
51 \cdot 8\end{array}$ & $\begin{array}{c}\text { Basic } \\
56 \cdot 4\end{array}$ \\
\hline $\begin{array}{l}\text { Assess the evidence and impact of health and health-care } \\
\text { interventions, programmes and services and apply these } \\
\text { assessments to practice }\end{array}$ & 91 & $+15 \cdot 2$ & $\begin{array}{l}\text { Advanced } \\
\quad 75 \cdot 0\end{array}$ & $\begin{array}{l}\text { Advanced } \\
48 \cdot 2\end{array}$ & $\begin{array}{l}\text { Basic } \\
50 \cdot 9\end{array}$ \\
\hline Needs assessment - assessing population needs using various methods ${ }^{\star}$ & 87 & $+14 \cdot 4$ & $\begin{array}{l}\text { Advanced } \\
69 \cdot 6\end{array}$ & $\begin{array}{l}\text { Intermediate } \\
49 \cdot 1\end{array}$ & $\begin{array}{c}\text { Basic } \\
43 \cdot 6\end{array}$ \\
\hline $\begin{array}{l}\text { Applied research, research and development - appraise, plan and } \\
\text { manage research, interpret research findings and apply in practice }\end{array}$ & 81 & $+23 \cdot 2$ & $\begin{array}{l}\text { Advanced } \\
80 \cdot 4\end{array}$ & $\begin{array}{l}\text { Intermediate } \\
47 \cdot 3\end{array}$ & $\begin{array}{l}\text { Basic } \\
60 \cdot 8\end{array}$ \\
\hline $\begin{array}{l}\text { Analysing the determinants of nutrition issues using a range of } \\
\text { information sources }\end{array}$ & 75 & $+17 \cdot 6$ & $\begin{array}{l}\text { Advanced } \\
83 \cdot 9\end{array}$ & $\begin{array}{l}\text { Intermediate } \\
\quad 44 \cdot 6\end{array}$ & $\begin{array}{c}\text { Basic } \\
49 \cdot 1\end{array}$ \\
\hline Scientific writing and dissemination of research & 19 & $-13 \cdot 9$ & $\begin{array}{l}\text { Advanced } \\
85 \cdot 7\end{array}$ & $\begin{array}{l}\text { Intermediate } \\
\quad 42 \cdot 9\end{array}$ & $\begin{array}{c}\text { Basic } \\
62 \cdot 3\end{array}$ \\
\hline Food monitoring and surveillance & 15 & $-12 \cdot 2$ & $\begin{array}{l}\text { Advanced } \\
54 \cdot 5\end{array}$ & $\begin{array}{l}\text { Intermediate } \\
41 \cdot 5\end{array}$ & $\begin{array}{l}\text { Basic-Intermediate } \\
47 \cdot 2 \text { ea }\end{array}$ \\
\hline $\begin{array}{l}\text { Improve the quality of health and health-care services and interventions } \\
\text { through audit and evaluation }\end{array}$ & 15 & $-12 \cdot 2$ & $\begin{array}{l}\text { Intermediate } \\
50 \cdot 0\end{array}$ & $\begin{array}{l}\text { Advanced } \\
69.6\end{array}$ & $\begin{array}{l}\text { Basic } \\
50 \cdot 0\end{array}$ \\
\hline Health economics and economic evaluation applications & 6 & $-5 \cdot 2$ & $\begin{array}{l}\text { Intermediate } \\
\quad 47 \cdot 3\end{array}$ & $\begin{array}{l}\text { Advanced } \\
54 \cdot 5\end{array}$ & $\begin{array}{l}\text { Basic } \\
87 \cdot 0\end{array}$ \\
\hline \multicolumn{3}{|l|}{ SOCIO-CULTURAL \& POLITICAL } & \multicolumn{3}{|c|}{ Modal response (most common) for each tier (round 3) (\%) } \\
\hline $\begin{array}{l}\text { Social sciences: Knowledge and understanding of the psychological, } \\
\text { social and cultural factors which influence food and dietary choices }\end{array}$ & 85 & $+15 \cdot 9$ & $\begin{array}{l}\text { Advanced } \\
64 \cdot 3\end{array}$ & $\begin{array}{l}\text { Intermediate } \\
50 \cdot 0\end{array}$ & $\begin{array}{c}\text { Intermediate } \\
46 \cdot 4\end{array}$ \\
\hline $\begin{array}{l}\text { Building community capacity building: community engagement, } \\
\text { collaboration, partnership, coalition building and community } \\
\text { dimensions of practice skills }{ }^{\star}\end{array}$ & 70 & $+6 \cdot 6$ & $\begin{array}{l}\text { Intermediate } \\
49 \cdot 1\end{array}$ & $\begin{array}{l}\text { Advanced } \\
69 \cdot 1\end{array}$ & $\begin{array}{l}\text { Intermediate } \\
\quad 40 \cdot 0\end{array}$ \\
\hline $\begin{array}{l}\text { Policy processes: policy development skills, influence policy development, } \\
\text { evaluate policy impacts, organisational politics }\end{array}$ & 57 & $+16 \cdot 4$ & $\begin{array}{l}\text { Advanced } \\
44 \cdot 6\end{array}$ & $\begin{array}{l}\text { Advanced } \\
80 \cdot 4\end{array}$ & $\begin{array}{l}\text { Basic } \\
64 \cdot 3\end{array}$ \\
\hline Advocacy - at government, organisation, profession levels & 38 & $+6 \cdot 4$ & $\begin{array}{l}\text { Advanced } \\
\quad 44 \cdot 6\end{array}$ & $\begin{array}{l}\text { Advanced } \\
76 \cdot 8\end{array}$ & $\begin{array}{l}\text { Basic } \\
58 \cdot 9\end{array}$ \\
\hline $\begin{array}{l}\text { Cultural competency: awareness, knowledge and skills that enable a } \\
\text { system, agency or professional to work effectively in cross-cultural situations }\end{array}$ & 55 & $-4 \cdot 4$ & $\begin{array}{l}\text { Advanced } \\
46 \cdot 4\end{array}$ & $\begin{array}{l}\text { Advanced } \\
52 \cdot 8\end{array}$ & $\begin{array}{l}\text { Advanced } \\
41 \cdot 8\end{array}$ \\
\hline \multicolumn{3}{|l|}{ PUBLIC HEALTH SERVICES } & \multicolumn{3}{|c|}{ Modal response (most common) for each tier (round 3) (\%) } \\
\hline $\begin{array}{l}\text { Intervention management: Design, plan, implement, monitor and } \\
\text { evaluate nutrition strategies and programmes for promoting health } \\
\text { and well-being of the population, that reduce inequalities }\end{array}$ & 96 & $+13 \cdot 4$ & $\begin{array}{l}\text { Advanced } \\
73 \cdot 2\end{array}$ & $\begin{array}{l}\text { Advanced } \\
63.0\end{array}$ & $\begin{array}{c}\text { Basic } \\
56 \cdot 4\end{array}$ \\
\hline $\begin{array}{l}\text { Principles and practice of health education, health promotion theory, } \\
\text { behaviour change and health promotion policy and programmes, } \\
\text { public health methods }{ }^{*}\end{array}$ & 94 & $+23 \cdot 6$ & $\begin{array}{l}\text { Advanced } \\
71 \cdot 4\end{array}$ & $\begin{array}{l}\text { Intermediate } \\
\quad 45 \cdot 5\end{array}$ & $\begin{array}{l}\text { Basic-Intermediate } \\
\quad 35 \cdot 2 \text { ea }\end{array}$ \\
\hline Knowledge of food and nutrition systems and community food needs ${ }^{\star}$ & 89 & $+16 \cdot 3$ & $\begin{array}{l}\text { Advanced } \\
\quad 75 \cdot 0\end{array}$ & $\begin{array}{l}\text { Intermediate } \\
48 \cdot 2\end{array}$ & $\begin{array}{c}\text { Intermediate } \\
41 \cdot 1\end{array}$ \\
\hline
\end{tabular}




\begin{tabular}{|c|c|c|c|c|c|}
\hline \multirow[b]{2}{*}{ Competency units } & \multirow{2}{*}{$\begin{array}{l}\% \text { rated as essential } \\
\text { (core) after two rounds }\end{array}$} & \multirow{2}{*}{$\begin{array}{l}\text { Stability: \% change } \\
\text { between rounds } 1 \text { and } 2\end{array}$} & \multicolumn{3}{|c|}{ Workforce category } \\
\hline & & & Specialist & Manager & Front-line \\
\hline Provide nutrition information/intelligence to various target groups ${ }^{*}$ & 89 & $+21 \cdot 5$ & $\begin{array}{l}\text { Advanced } \\
\quad 62 \cdot 5\end{array}$ & $\begin{array}{l}\text { Basic } \\
40 \cdot 0\end{array}$ & $\begin{array}{l}\text { Advanced } \\
\quad 44 \cdot 6\end{array}$ \\
\hline Provision of preventive nutrition programmes ${ }^{\star}$ & 79 & $+14 \cdot 3$ & $\begin{array}{l}\text { Advanced } \\
63 \cdot 6\end{array}$ & $\begin{array}{l}\text { Advanced } \\
48 \cdot 1\end{array}$ & $\begin{array}{l}\text { Intermediate } \\
37 \cdot 0\end{array}$ \\
\hline $\begin{array}{l}\text { Building capacity of the health workforce through training, up-skilling } \\
\text { and mentoring }\end{array}$ & 17 & -1.9 & $\begin{array}{l}\text { Advanced } \\
51.9\end{array}$ & $\begin{array}{l}\text { Advanced } \\
51.9\end{array}$ & $\begin{array}{l}\text { Basic } \\
47 \cdot 2\end{array}$ \\
\hline $\begin{array}{l}\text { Service and programme prioritisation based on identified needs, their } \\
\text { potential impact, as defined by objective measurable criteria }\end{array}$ & 47 & $-6 \cdot 8$ & $\begin{array}{l}\text { Intermediate } \\
53 \cdot 7\end{array}$ & $\begin{array}{l}\text { Advanced } \\
\quad 74 \cdot 5\end{array}$ & $\begin{array}{l}\text { Basic } \\
68 \cdot 5\end{array}$ \\
\hline Health-care systems knowledge & 28 & $-15 \cdot 5$ & $\begin{array}{l}\text { Intermediate } \\
53 \cdot 7\end{array}$ & $\begin{array}{l}\text { Advanced } \\
79 \cdot 2\end{array}$ & $\begin{array}{l}\text { Intermediate } \\
42 \cdot 3\end{array}$ \\
\hline Provision of clinical nutrition services & 2 & $-3 \cdot 4$ & $\begin{array}{l}\text { Basic } \\
44 \cdot 6\end{array}$ & $\begin{array}{l}\text { Basic } \\
58 \cdot 2\end{array}$ & $\begin{array}{l}\text { Basic } \\
45 \cdot 5\end{array}$ \\
\hline COMMUNICATION & & & \multicolumn{3}{|c|}{ Modal response (most common) for each tier (round 3) (\%) } \\
\hline Interpersonal communication ${ }^{\star}$ & 92 & $+16 \cdot 6$ & $\begin{array}{l}\text { Advanced } \\
69 \cdot 1\end{array}$ & $\begin{array}{l}\text { Advanced } \\
74 \cdot 5\end{array}$ & $\begin{array}{l}\text { Advanced } \\
69 \cdot 1\end{array}$ \\
\hline Written communication $^{\star}$ & 91 & $+19 \cdot 9$ & $\begin{array}{l}\text { Advanced } \\
\quad 83.6\end{array}$ & $\begin{array}{l}\text { Advanced } \\
76 \cdot 4\end{array}$ & $\begin{array}{l}\text { Intermediate } \\
53 \cdot 7\end{array}$ \\
\hline Media utilisation & 48 & $+5 \cdot 0$ & $\begin{array}{l}\text { Intermediate } \\
\quad 43 \cdot 6\end{array}$ & $\begin{array}{l}\text { Advanced } \\
56 \cdot 4\end{array}$ & $\begin{array}{l}\text { Basic } \\
52 \cdot 7\end{array}$ \\
\hline $\begin{array}{l}\text { Grantsmanship - submission writing to access resources to enable } \\
\text { intervention and service delivery }\end{array}$ & 25 & $-7 \cdot 1$ & $\begin{array}{l}\text { Advanced } \\
53 \cdot 7\end{array}$ & $\begin{array}{l}\text { Advanced } \\
\quad 63.6\end{array}$ & $\begin{array}{l}\text { Basic } \\
63 \cdot 6\end{array}$ \\
\hline Social marketing & 15 & $-8 \cdot 5$ & $\begin{array}{l}\text { Intermediate-Advanced } \\
36 \cdot 4\end{array}$ & $\begin{array}{l}\text { Advanced } \\
\quad 49 \cdot 1\end{array}$ & $\begin{array}{l}\text { Basic } \\
52 \cdot 7\end{array}$ \\
\hline Able to speak more than one language & 15 & $-10 \cdot 8$ & $\begin{array}{c}\text { Basic } \\
41 \cdot 5\end{array}$ & $\begin{array}{c}\text { Basic } \\
41 \cdot 5\end{array}$ & $\begin{array}{c}\text { Basic } \\
45 \cdot 3\end{array}$ \\
\hline Dietary counselling & 11 & $-5 \cdot 7$ & $\begin{array}{l}\text { Basic } \\
38 \cdot 9\end{array}$ & $\begin{array}{l}\text { Basic } \\
66 \cdot 0\end{array}$ & $\begin{array}{l}\text { Advanced } \\
50.0\end{array}$ \\
\hline MANAGEMENT \& LEADERSHIP & & & \multicolumn{3}{|c|}{ Modal response (most common) for each tier (round 3) (\%) } \\
\hline Strategic planning ${ }^{*}$ & 77 & $+15 \cdot 3$ & $\begin{array}{c}\text { Intermediate-Advanced } \\
44.4 \mathrm{ea}\end{array}$ & $\begin{array}{l}\text { Advanced } \\
89 \cdot 1\end{array}$ & $\begin{array}{l}\text { Basic } \\
74 \cdot 5\end{array}$ \\
\hline Team building ${ }^{*}$ & 68 & $+8 \cdot 3$ & $\begin{array}{l}\text { Advanced } \\
50 \cdot 0\end{array}$ & $\begin{array}{l}\text { Advanced } \\
79 \cdot 6\end{array}$ & $\begin{array}{c}\text { Intermediate } \\
40 \cdot 7\end{array}$ \\
\hline Computing and technology utilisation/information technology ${ }^{*}$ & 68 & $+16 \cdot 2$ & $\begin{array}{l}\text { Advanced } \\
47 \cdot 2\end{array}$ & $\begin{array}{c}\text { Intermediate } \\
54.5\end{array}$ & $\begin{array}{c}\text { Intermediate } \\
52 \cdot 7\end{array}$ \\
\hline Negotiation skills & 31 & $-8 \cdot 9$ & $\begin{array}{c}\text { Intermediate } \\
50 \cdot 9\end{array}$ & $\begin{array}{l}\text { Advanced } \\
85 \cdot 2\end{array}$ & $\begin{array}{l}\text { Basic } \\
45 \cdot 3\end{array}$ \\
\hline Systems thinking skills & 19 & $-9 \cdot 6$ & $\begin{array}{c}\text { Intermediate } \\
51 \cdot 9\end{array}$ & $\begin{array}{l}\text { Advanced } \\
79 \cdot 6\end{array}$ & $\begin{array}{l}\text { Basic } \\
60 \cdot 4\end{array}$ \\
\hline Leadership: motivation, dedication, vision (personal attributes) & 38 & $-16 \cdot 2$ & $\begin{array}{l}\text { Advanced } \\
55.6\end{array}$ & $\begin{array}{l}\text { Advanced } \\
90 \cdot 9\end{array}$ & $\begin{array}{l}\text { Basic } \\
50 \cdot 0\end{array}$ \\
\hline
\end{tabular}




Competency units

Organisational behaviour, organisational management and organisational change Personnel (staff) management

Financial planning/management skills

$\%$ rated as essential Stability: \% change

\section{NUTRITION SCIENCE}

Food composition*

Food guidance and goals ${ }^{\star}$

\section{Nutritional requirements ${ }^{\star}$}

Nutrition intervention strategy options and selection ${ }^{\star}$

Lifespan nutrition*

Assessment of food, nutrient and dietary intakes and status in populations ${ }^{\star}$

Physical activity assessment

Food science

Dietetic management of disease

Physical fitness assessment

Assessment of food, nutrient and dietary intakes and status in individuals

\section{PROFESSIONAL}

Professional accountability and social responsibility ${ }^{*}$

Ethics of public health nutrition practice ${ }^{\star}$

Commitment to continual competency development and lifelong learning

Able and willing to consult and refer to others when extra

competencies are required*

Reflective practice to enhance performance ${ }^{*}$ (core) after two rounds between rounds 1 and 2

\begin{tabular}{rccc}
-15.6 & Intermediate & Advanced & Basic \\
& $61 \cdot 8$ & $\mathbf{9 2 \cdot 7}$ & $67 \cdot 3$ \\
-10.9 & Intermediate & Advanced & Basic \\
& $59 \cdot 3$ & $\mathbf{8 9 \cdot 1}$ & $66 \cdot 7$ \\
-6.7 & Intermediate & Advanced & Basic \\
& 58.5 & $\mathbf{8 8 . 9}$ & 76.9 \\
\hline
\end{tabular}

Modal response (most common) for each tier (round 3) (\%)

\begin{tabular}{ccc} 
Advanced & Basic & Intermediate \\
$\mathbf{8 1 \cdot 8}$ & $55 \cdot 6$ & $47 \cdot 3$ \\
Advanced & Intermediate & Advanced \\
$\mathbf{8 3 \cdot 9}$ & $41 \cdot 1$ & $47 \cdot 3$ \\
Advanced & Intermediate & Advanced \\
$\mathbf{8 3} \cdot \mathbf{9}$ & $41 \cdot 8$ & $49 \cdot 1$ \\
Advanced & Advanced & Intermediate \\
$\mathbf{7 8 \cdot 6}$ & $45 \cdot 5$ & $48 \cdot 2$ \\
Advanced & Intermediate & Intermediate \\
$\mathbf{8 2 \cdot 1}$ & $39 \cdot 3$ & $41 \cdot 1$ \\
Advanced & Basic & Intermediate \\
$\mathbf{9 1 \cdot 1}$ & $41 \cdot 1$ & $41 \cdot 8$ \\
Intermediate & Basic & Intermediate \\
$44 \cdot 6$ & $60 \cdot 7$ & $52 \cdot 7$ \\
Advanced & Basic & Basic \\
$41 \cdot 5$ & $67 \cdot 9$ & $57 \cdot 7$ \\
Basic & Basic & Intermediate \\
$35 \cdot 7$ & $\mathbf{7 4 . 5}$ & $37 \cdot 0$ \\
Intermediate & Basic & Intermediate \\
$40 \cdot 7$ & $67 \cdot 9$ & $51 \cdot 9$ \\
Advanced & Basic & Advanced \\
$52 \cdot 7$ & $64 \cdot 3$ & $41 \cdot 1$ \\
\hline
\end{tabular}

Modal response (most common) for each tier (round 3) (\%)

$\begin{array}{ccc}\text { Advanced } & \text { Advanced } & \text { Advanced } \\ \mathbf{7 3 \cdot 2} & \mathbf{6 9 \cdot 1} & 53 \cdot 7 \\ \text { Advanced } & \text { Advanced } & \text { Advanced } \\ \mathbf{7 8 \cdot 6} & 64 \cdot 3 & 57 \cdot 4 \\ \text { Advanced } & \text { Advanced } & \text { Advanced } \\ \mathbf{8 0 \cdot 4} & 64 \cdot 3 & 60 \cdot 0 \\ \text { Advanced } & \text { Advanced } & \text { Advanced } \\ \mathbf{8 0 \cdot 4} & \mathbf{7 5 \cdot 0} & 63 \cdot 6 \\ \text { Advanced } & \text { Advanced } & \text { Advanced } \\ 66 \cdot 1 & 62 \cdot 5 & 47 \cdot 3\end{array}$


is that employers know what competencies are needed of public health nutritionists and/or have adequately reflected on this question. The limited variability in response distributions for competency ratings by academics $v$. employers throughout the whole study suggests that this categorisation of key stakeholders (academic $v$. employers) does not isolate differences in experience and opinion, at least in terms of how these are expressed in competency ratings.

As most of the competencies defined as essential (twenty-six of twenty-nine) did not achieve consensus stability over two rounds, further survey rounds would have been required to achieve this aspect of consensus development in the Delphi method. All of the changes between rounds were in favour of increasing agreement, indicating that panellists were focusing their responses consistent with the overall panel. The competency units rated as essential in the current study matched closely the earlier agreement identified in the 2003 Delphi study ${ }^{(10)}$. Many of the competency units identified as essential in the current study mirror competencies isolated in health promotion $^{(27)}$ and public health ${ }^{(28)}$ practice disciplines. This is not surprising given that the original Delphi survey competency units tested were largely derived from the health promotion and public health literature. This is consistent with the almost universal support among panellists for the proposition that there are many crosscutting competencies between public health and public health nutrition. It also reflects the position suggested in earlier work ${ }^{(18)}$ that public health nutrition as a field of practice is more closely aligned as a specialisation within public health than as a specialisation within nutrition. This has been reinforced more recently ${ }^{(29)}$ and is open to debate. Given the nutrition-specific disciplinary focus of public health nutrition, it is not surprising to note the very high proportion of panellists rating competencies within the nutrition science competency domain as essential. This supports earlier opinions expressed about the central importance of competence in nutritional sciences for public health nutritionists ${ }^{(18)}$.

This attempt to delineate the level of competency required by different workforce categories in the current study recognises the many players in the public health nutrition workforce and the competency development priorities for a specialist workforce. These data should be of value to workforce developers and educators, particularly in the European context where workforce specialisation is limited, because they help prioritise workforce development needs.

The similar views of the two subgroups of panel members support the concept of core competencies recognised by practitioners working at different levels in the public health nutrition field. The high level of agreement on essential competencies among this pan-European panel supports the idea of essential competencies applicable across countries and in different contexts ${ }^{(10)}$. The strong 
consensus developed on competencies essential for efficient public health nutrition practice can be used to develop the public health nutrition workforce in Europe, by providing a framework for benchmarking curriculum and assessment among existing specialist education programmes and to inform new programme development. The essential competencies identified also enable practitioners and students to reflect on their own competencies and assess their continuing education needs.

The breadth of the competencies defined as essential in the current study indicates that the focus of workforce development should be on forming efficient work teams or workforce tiers with the required competency mix. The competency priorities identified for specialists also provide direction for the development of a public health nutrition specialist in countries that do not have such roles. This need for specialists (i.e. a designated public health nutritionist) has been a consistent feature of workforce capacity building in other parts of the world such as Australia, the USA and Canada.

The present study provides the data to support the development of a number of workforce development instruments based on consensus and priority in the European context. These competency standards can be used to assist with human resource management (position descriptions, recruitment, etc.). It also builds on the limited workforce development research in the public health nutrition arena, with the potential to contribute to more strategic workforce development in Europe and at a global level.

Lack of information regarding the public health nutrition workforce in Europe is an obvious barrier to workforce development. This Delphi study provides information to aid in the workforce development of public health nutrition practice by gathering expertise and intelligence from a large group of geographically dispersed public health nutrition experts. The results show agreement about essential competencies for the public health nutrition workforce, especially for elements within the nutrition science as well as the professional, analytical and public health service competency domains. The diverse background of panellists gives added value to the statements reaching the consensus limit, further supporting the concept of core competencies and workforce functions transferable between countries.

\section{Acknowledgements}

This Delphi study is a part of a pan-European project, JobNut, which was financed by the Leonardo Community Vocational Training Programme (agreement number 2003320). R.H and A.Y. confirm that they had no conflict of interests relating to this research other than their roles respectively as Deputy Editor and Editor-in-Chief of the journal, and had no role in terms of peer review or approval. S.J. and I.T had no conflicts of interest. S.J. participated in the design of the Delphi study and implemented the study as a research student in nutrition. She had a principal role in Delphi data analysis and reporting. R.H. conceptualised the study and had a principal role in methods design and data analysis. I.T. participated in the survey design and data analysis. A.Y. contributed to conceptualising the study and was the project's manager. All authors contributed to the drafting and final editing of this manuscript. The generous contribution and input from the Delphi panel members is deeply appreciated. Obviously, the current study would not have been possible without the efforts of the stakeholders, giving their time and sharing their expertise. The Expert Panel comprised the following individuals: Katica Antonic Degac (Croatia); Katherine O'Doherty Jensen, Lotte Holm, Sjurdur Olsen (Denmark); Arja Erkkilä, Irja Haapala, Jaakko Kaprio, Pekka Puska (Finland); Ambroise Martin (France); Helmut Oberritter (Germany); Theodora Psaltopoulou, Éva Martos (Greece); Andrea Lugasi (Hungary); Elva Gísladóttir, Ingibjörg Gunnarsdóttir, Laufey Steingrímsdóttir (Iceland); Cecily Kelleher, Corina Glennon Slattery, Eileen Gibney, Geraldine Quinn, John Kearney, Linda Hogan, Nick Kennedy (Ireland); Domenico Palli (Italy); Albertas Barzda, Algis Abaravicius (Lithuania); Yvette Azzopardi (Malta), Alma van der Greft, Annemiek van Bolhuis, Joop van Raaij (Netherlands); Arne Oshaug, Knut-Inge Klepp, Øydis Ueland (Norway); Lucjan Szponar (Poland); Maria Daniel Vaz de Almeida (Portugal); Cirila Hlastan-Ribič, Jozica Maucec-Zakotnik (Slovenia); Carmen Pérez-Rodrigo, Emilio Martínez de Victoria Muñoz, Gregorio Varela Moreiras, Lluís Serra Majem, Victòria Arija (Spain); Agneta Yngve, Anki Sundin, Annica Sohlström, Gudrun Ahlin, Gunnar Johansson (Sweden); Anne Heughen, Ailsa Welch, Alison Nelson, Barrie Margetts, Claire Schofield, Diane Talbot, Elizabeth Lund, Jackie Landman, Jessica Swann, Kim Procter, Rachel Thompson, Sheela Reddy, Sinead McElhone, Susan Jebb, Wendy Wills (United Kingdom).

\section{References}

1. Baillie E, Bjarnholt C, Gruber M et al. (2009) A capacity building conceptual framework for public health nutrition practice. Public Health Nutr 12, 1031-1038.

2. Hughes R (2006) A socio-ecological analysis of the determinants of national public health nutrition workforce capacity: Australia as a case study. Fam Community Health 29, 55-67.

3. Public Health Foundation (2009) Council on Linkages: Core Competencies for Public Health Professionals. http:// www.phf.org/link/core-061109.htm (accessed March 2010).

4. Galway Consensus Conference (2008) Toward domains of core competency for building global capacity in health promotion: The Galway Consensus Conference Statement. 
http://www.iuhpe.org/uploaded/Activities/Cap_building/Galway_ Consensus_Statement.pdf (accessed March 2010).

5. Health Scotland (2005) Competencies for Health Promotion Practitioners: Report of a Working Group. Edinburgh: Health Scotland.

6. Public Health Agency of Canada (2007) Core competencies for public health in Canada: Release 1.0. http://www.phacaspc-gc.ca/ccph-cesp/index-eng.php (accessed March 2010).

7. Hughes R (2005) A competency framework for public health nutrition workforce development. Australian Public Health Nutrition Academic Collaboration. http://www. aphnac.com/media/files/252.pdf (accessed March 2010).

8. Haughton B, Story M \& Keir B (1998) Profile of public health nutrition personnel: challenges for population/ system-focused roles and state-level monitoring. J Am Diet Assoc 98, 664-670.

9. Yngve A, Sjostrom M, Warm D et al. (1999) Effective promotion of healthy nutrition and physical activity in Europe requires skilled and competent people; European Master's Programme in Public Health Nutrition. Public Health Nutr 2, 449-452.

10. Hughes R (2004) Competencies for effective public health nutrition practice: a developing consensus. Public Health Nutr 7, 683-691.

11. Wass V, van der Vleuten C, Shatzer J et al. (2001) Assessment of clinical competence. Lancet 357, 945-949.

12. Sims L (1979) Identification and evaluation of competencies of public health nutritionists. Am J Public Health 69, 1099-1105.

13. Story M, Neumark-Stzainer D, Ireland M et al. (2000) Adolescent health and nutrition: a survey of perceived knowledge and skill competencies and training interests among dietitians working with youth. J Am Diet Assoc 100, 362-364.

14. Nutrition Society of Australia (2007) Specialist Competencies in Nutrition Science. Melbourne: Nutrition Society of Australia.

15. Landman J (2001) Training in public health nutrition: symposium at the 17th International Congress of Nutrition, Vienna. Public Health Nutr 4, 1301-1302.

16. UK Voluntary Register of Nutritionists (2007) Professional Registration in Nutrition: Code of Ethics and Statement of Professional Conduct. London: The Nutrition Society.
17. Hughes R (2003) Competency development needs of the Australian public health nutrition workforce. Public Health Nutr 6, 839-847.

18. Hughes R (2003) Public health nutrition workforce composition, core functions, competencies and capacity: perspectives of advanced-level practitioners in Australia. Public Health Nutr 6, 607-613.

19. Public Health Foundation (2002) Council of Linkages in Practice: Core Competencies for Public Health Professionals 2001. https://www.train.org/Competencies/compWOskill. aspx?tabID $=94$ (accessed March 2010).

20. Murphy M, Black N, Lamping D et al. (1998) Consensus development methods, and their use in clinical guideline development. Health Technol Assess 2, 1-88.

21. Rowe G \& Wright G (1999) The Delphi technique as a forecasting tool: issues and analysis. Int J Forecasting 15, 353-375.

22. Powell C (2003) The Delphi technique: myths and realities. J Adv Nurs 41, 376-382.

23. Keeney S, Hassen F \& McKenna H (2006) Consulting the oracle: ten lessons from using the Delphi technique in nursing research. J Adv Nurs 53, 205-212.

24. Duffield C (1993) The Delphi technique: a comparison of results obtained using two expert panels. Int J Nurs Stud 30, 227-237.

25. Hughes R (2004) Employers expectations of core functions and competencies for public health nutrition practice in Australia. Nutr Diet 61, 105-111.

26. Torheim LE, Granli GI, Barikmo I et al. (2009) A survey among potential employers for developing a curriculum in public health nutrition. Public Health Nutr 12, 1039-1045.

27. Hyndman B (2009) Towards the development of skillsbased health promotion competencies: the Canadian experience. Glob Health Promot 16, 51-55.

28. UK Public Health Register (2006) Application for Defined Specialist Accreditation onto the UK Public Health Register by Retrospective Portfolio Assessment: Framework and Guidance. London: UK Public Health Register.

29. Cannon G (2009) Out of the Box. Public Health Nutr 12, 1301-1304. 